\title{
A África no Brasil: grupos étnicos e orpanização social em São Paulo no século YlY
}

Regiane Augusto de Mattos*

Resumo. Este artigo tem por objetivo apresentar um perfil dos grupos étnicos dos africanos na cidade de São Paulo, na primeira metade do século XIX, salientando as suas formas de organização social, em particular no que se refere às manifestações culturais e religiosas. Pretende-se discutir, baseando-se no conceito de grupo étnico fornecido pelo antropólogo Fredrik Barth, as formas de atribuição e de identificação desses grupos por agentes externos como a Igreja Católica e os proprietários de escravos. Esse conceito também tem como pressuposto a incorporação pelos próprios africanos, que passaram a se identificar com esses grupos éticos direcionando suas formas de organização, sobretudo por meio da associação em irmandades religiosas, "ajuntamentos” em batuques, capoeiras, danças. A intenção é perceber como a incorporação a determinados grupos étnicos direcionou as formas de organização, as manifestações de suas tradições por meio de aspectos culturais e religiosos, a relação com os diferentes grupos étnicos e com outras camadas da sociedade. Palavras-chave: População africana. Grupos étnicos.

Formas de organização social.

* Mestranda em História Social na Universidade de São Paulo, com orientação da Profa. Dra. Leila Leite Hernandez.

Anos 90, Porto Alegre, v. 12, n. 21/22, p.151-172, jan./dez. 2005 
A África no Brasil: grupos étnicos e organização social em São Paulo...

Enquanto etnicidade, a escolha assumiu grande importância no processo de criação de veículos de socialização no Brasil; muitas das mesmas funç̃oes e necessidades encontravam-se presentes entre grupos étnicos e de parentesco no interior da Africa. O transporte para o Novo Mundo destruiu as unidades familiares e separou as pessoas do mesmo grupo étnico, destruindo, deste modo, os vínculos que uma etnia ou um grupo de parentesco compartilhado fornecia às pessoas que se moviam pelo interior da África, mas não destruiu a consciência de uma identificação com base na etnia e nos grupos de parentesco e de família, ou em parentesco ficticio, criado entre os companheiros de embarcação (malungos) nos navios negreiros. Eram esta consciência e esta memória coletiva que possibilitavam que as pessoas de descendência africana reconstruíssem sua identidade através da família e da etnicidade no Brasil, promovendo um amortecedor contra os cruéis aspectos da instituição escravista.

A. J. R. Russel-Wood (2001)

É sabido que, durante muitos anos, o tráfico atlântico de escravos permaneceu vigente e trouxe do continente africano milhares de negros que abasteceram as diferentes regiões do Brasil. Escravos de diversas origens e lugares se misturavam nos navios negreiros e desembarcavam nos principais portos brasileiros. Vários trabalhos foram elaborados por antropólogos, sociólogos e historiadores com o intuito de desvendar a procedência étnica desses escravos africanos que passaram a compor o contingente populacional brasileiro.

Até meados do século XX, estudiosos como Nina Rodrigues, Arthur Ramos, Melville J. Herskovits e Fernando Ortis consideravam os diferentes grupos de escravos africanos que foram trazidos pelo tráfico para o Novo Mundo como etnias originais. Ademais, tinham como pressuposto a possibilidade de esses grupos preservarem aspectos culturais intactos, partindo destes para determinar a etnia à qual pertenciam. Dessa forma, utilizavam, metodologicamente, a associação entre grupo étnico e traços de cultura originais, não levando em conta as transformações ocasionadas pela diáspora.

Na década de 1960, houve uma tendência, nas ciências humanas, em questionar a definição de grupo étnico como um ele-

Anos 90, Porto Alegre, v. 12, n. 21/22, p.151-172, jan./dez. 2005 
mento pronto, fechado, com fronteiras bem delimitadas. $\mathrm{O}$ antropólogo Fredrik Barth participou desse debate teórico considerando grupo étnico um conceito em constante formação. As fronteiras que o demarcam são problemáticas, não há uma idéia preconcebida das estruturas e da sua composição.

Esse autor inovou o debate ao propor o rompimento da relação direta entre fronteiras étnicas e aspectos culturais, criticando a idéia de compartilhá-los como uma característica de definição do grupo étnico. Barth considera os traços culturais como um dos resultados da organização desses grupos. Esses traços culturais que fazem parte das características do grupo étnico são escolhidos pelos próprios integrantes do grupo, podendo mudar, pois também estão em constante transformação (Barth, 1997, p.187-227).

Outro aspecto inovador que Barth trouxe ao debate sobre etnicidade diz respeito à própria identificação de um grupo étnico. Segundo esse autor, "grupos étnicos são categorias de atribuição e identificação realizadas pelos próprios atores e, assim, têm características de organizar a interação entre as pessoas." (idem, p.189). Para Barth, os grupos étnicos são formados pelos próprios indivíduos envolvidos a partir de uma relação tanto de atribuição quanto de identificação. Nesse aspecto, o autor atribui ao indivíduo uma capacidade política proporcionada pela possibilidade de se auto-definir pertencente, e não apenas ser inserido, a determinado grupo.

No que se refere ao conceito de etnia, utilizamos a definição de Fredrik Barth dada no artigo já citado Grupos étnicos e suas fronteiras, considerando-a como termo intercambiável de grupo étnico. No caso dos escravos africanos, particulariza-se a reorganização desses grupos nos momentos de embarque no continente africano e, posteriormente, desembarque no Brasil.

Esses grupos étnicos, obrigados a irem para a outra costa do Atlântico, não eram os mesmos que existiam antes de serem capturados e transformados em escravos. Foram reunidos em supostas 
A África no Brasil: grupos étnicos e organização social em São Paulo...

etnias por conveniência do tráfico de escravos. Essa reunião de grupos étnicos promovida por agentes externos, como os proprietários de escravos e a Igreja Católica, acabou sendo reelaborada e internalizada pelos próprios indivíduos classificados, resultando numa identidade étnica que direcionou as formas de organização, as alianças, a vida religiosa, as reuniões matrimoniais, bem como redefiniu as relações entre os diferentes grupos.

A proposta deste artigo é mostrar, tendo como base o conceito de grupo étnico fornecido por Fredrik Barth, as formas de atribuição e de identificação desses grupos por agentes externos como a Igreja Católica e os proprietários de escravos, bem como a incorporação pelos próprios africanos que passaram a se identificar com esses grupos éticos, direcionando suas formas de organização, sobretudo por meio da associação em irmandades religiosas, "ajuntamentos" em batuques, capoeiras, danças. Essa identificação a determinados grupos levava em conta características que consideravam em comum como a língua, a ascendência e a visão de mundo.

\section{A identificação étnica realizada pela Igreja}

Sabemos que assim que o escravo chegava em terras brasileiras, seu proprietário encaminhava-o para a paróquia mais próxima, onde era batizado. A partir desse momento ele era considerado pertencente ao "mundo dos cristãos". Dessa forma, o batismo era utilizado como mecanismo de inserção dessa população não somente nos costumes dos brancos europeus, mas também na própria sociedade brasileira. Esses registros identificavam a população, trazendo informações sobre o nome do batizado, dos pais ou, no caso dos africanos, dos proprietários, bem como a sua origem étnica, constituindo-se uma importante fonte documental para o estudo dos grupos étnicos. ${ }^{1}$ 
Para uma melhor compreensão das formas de classificação dos grupos étnicos realizada pela Igreja Católica, resolvemos agrupálos de acordo com as áreas do continente africano. A historiografia sobre o tráfico de escravos atribui à África três grandes regiões abastecedoras de cativos para a América: Centro-Oeste, Oriental e Ocidental. ${ }^{2}$ Considerando essa divisão por áreas do continente africano, os registros revelam as informações a respeito dos grupos étnicos constantes na Tabela 1.

\section{Tabela 1 - Origem dos escravos africanos}

\begin{tabular}{lrr}
\hline Origem & No. & \multicolumn{1}{c}{$\%$} \\
\hline Guiné $^{1}$ & 366 & 37,70 \\
África $^{2}$ & 224 & 23,06 \\
da Costa $^{\text {Costa da África }}$ & 150 & 15,45 \\
Centro-Oeste $^{3}$ & 68 & 7,00 \\
Ocidental $^{4}$ & 66 & 6,80 \\
Costa da Guiné $_{\text {Oriental }}^{5}$ & 51 & 5,25 \\
Total $^{5}$ & 32 & 3,29 \\
\hline
\end{tabular}

Fonte: Arquivo da Cúria Metropolitana de São Paulo (ACMSP), Registros de Batismo. Livros 5-2-23, 5-2-20, 3-2-2, 3-2-13, 6-1-33, 5-3-26, 5-3-32, 6-2-16, 2-2-12.

${ }^{1}$ Essa expressão abrange os termos "da Guiné" e "gentio da Guiné".

${ }^{2}$ Essa expressão abrange os termos "africano", "africano de nação" e "de nação".

${ }^{3}$ Essa expressão abrange os termos "angola", cabinda", "cassange", "congo", "munjolo" e "rebolo".

${ }^{4}$ Essa expressão abrange o termo "mina".

${ }^{5}$ Essa expressão abrange o termo "moçambique".

Notamos que, em 13,5\% dos registros de batismo (somando as regiões da África Ocidental, Centro-Oeste e Oriental), a Igreja identificou esses africanos com grupos étnicos específicos, enquanto em $86,5 \%$ utilizou termos genéricos, como "gentio da Guiné" e "Costa da África". Haveria certa dificuldade em realizar a distinção entre os diversos grupos. Dificuldade talvez decorrente da 
A África no Brasil: grupos étnicos e organização social em São Paulo...

dependência da declaração do próprio africano, que não estava familiarizado com a língua e/ou da ausência do proprietário no momento do registro. Por outro lado, podemos pensar que essas informações não tão específicas quanto à origem étnica dos africanos fossem suficientes, aos olhos dos religiosos, para inseri-los na sociedade paulista e promover a sua conversão à doutrina católica por meio dos sacramentos como o batismo.

Outra fonte documental que traz informações sobre a origem étnica dos africanos são os registros de óbito. Considerando a divisão por áreas do continente africano, encontramos as referências registradas na Tabela 2.

De acordo com os registros de óbito analisados, alguns termos utilizados nos registros são muito abrangentes e não nos permitem identificar a região exata da África, como nos casos em que aparecem os termos "Costa da África", "da Costa", "gentio da Guiné" e "Costa da Guiné" - 89,15\%. Por outro lado, os termos mais específicos, que revelam os grupos étnicos africanos, encontram-se em 10,85\% se somarmos as áreas Centro-Oeste, Ocidental e Oriental do continente africano.

Isso nos mostra, ainda mais intensamente, a incapacidade da Igreja Católica em determinar os grupos étnicos dos escravos e libertos que viveram na cidade de São Paulo. Como foi dito anteriormente, esse fato pode ser em decorrência da dificuldade dos religiosos em reconhecer a origem. No entanto, poderia não se configurar apenas uma dificuldade, mas também um desinteresse por parte da Igreja em distinguir as diferentes origens. No entanto, revela um procedimento distinto utilizado pela Igreja Católica, isto é, uma classificação, levando em conta a doutrina cristã de catequização, daí o uso de "gentio" com o significado de pagão, nivelando todos os escravos africanos. 
Regiane Augusto de Mattos

Tabela 2 - Origem dos escravos e libertos africanos

\begin{tabular}{lrr}
\hline Área da África & Total & \multicolumn{1}{c}{$\%$} \\
\hline Guiné & \\
da Costa & 529 & 59,85 \\
Centro-Oeste $^{2}$ & 139 & 15,72 \\
África $^{3}$ & 73 & 8,25 \\
Costa da África $^{\text {Costa da Guiné }}$ & 59 & 6,68 \\
Ocidental $^{4}$ & 31 & 3,50 \\
Oriental $^{5}$ & 30 & 3,40 \\
Total & 22 & 2,48 \\
\hline
\end{tabular}

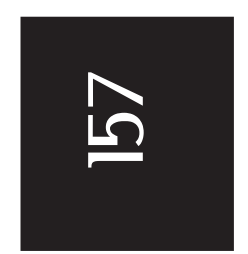

Fonte: ACMSP, Registros de Óbito. Livros: 2-2-25, 2-2-30, 3-1-38, 3-1-36, 5-3-36, 2-2-12.

${ }^{1}$ Essa expressão abrange os termos "da Guiné" e "gentio da Guiné".

${ }^{2}$ Essa expressão abrange os termos "angola", cabinda", "cassange", "congo", "munjolo", "rebolo", "benguela", "cabindá” e "ganguela".

${ }^{3}$ Essa expressão abrange os termos "africano", "africano de nação", "de nação", "África”, "do gentio", "gentio de nação” e "nação africana”.

${ }^{4}$ Essa expressão abrange o termo "Costa da Mina".

${ }^{5}$ Essa expressão abrange o termo "moçambique".

Obs.: há um registro não classificado: "muumbé".

Mesmo verificando uma preocupação pequena da Igreja Católica em identificar esse contingente populacional, é interessante atentar para os termos mais específicos utilizados. Percebemos que são designações semelhantes às apresentadas no restante do Império, em regiões onde a população africana permaneceu em grande quantidade, como no Rio de Janeiro e em Salvador. São expressões comuns e difundidas largamente pelo tráfico atlântico.

\section{A identificação étnica realizada pelos proprietários de escravos}

Nesse momento, voltamo-nos para as formas de identificação étnica fornecida pelos proprietários de escravos, debruçando-nos

Anos 90, Porto Alegre, v. 12, n. 21/22, p.151-172, jan./dez. 2005 
A África no Brasil: grupos étnicos e organização social em São Paulo...

sobre os anúncios de cativos fugidos e à venda nos jornais publicados na cidade de São Paulo. Esses anúncios permitem-nos não apenas perceber a reação dos escravos materializada em fugas diante da opressão do sistema escravista, mas também revelam de que maneira os proprietários identificavam essa população, sobretudo etnicamente. Um anúncio muito peculiar nos mostra a descrição detalhada de alguns africanos, apontando traços físicos como altura, idade e até mesmo marcas próprias da "nação" de origem.

No dia 14 de Junho do corrente annos fugirão da Fazenda denominada Bellem do districto de Juqueri, do Sargentomor Joaquim Floriano de Godoi 3 escravos inda alguma coiza buçaes, cujos nomes e signaes são os seguintes João nação muxava, baixo, cheio de corpo, o rosto estrelado, bons dentes - Romão, Nação Monjolo, alto, cara riscada ao comprido, piza com os calcanhares primeiro que os dedos - Manoel, Nação Benguela, boa estatura, cara liza, beiços vermelhos, bons dentes - todos forão de camiza e siroula de algodão, coletes de baeta roxa forro azul, botons redondos amarelos, mantas de algodão riscado, baetas e chapeos de palha. Quem os puder aprehender, e os entregar nesta Cidade ao dicto Godoi, será gratificado. ${ }^{3}$

Uma das características mais recorrentes utilizadas para a distinção dos grupos étnicos são os "sinais de nação". Como já vimos na historiografia e, muitas vezes, em pranchas pintadas pelos cronistas, as escarificações presentes, principalmente na face dos africanos, possuíam formas que poderiam revelar a "etnia" a que pertenciam. Vejamos ainda anúncios que determinam os grupos étnicos associando-o às suas marcas específicas:

A Joaquim Alves Alvim fugio, ha 3 mezes um preto de nação Congo, de estatura mediana, feições tristes, parece ja velho, com uns signaes da nação no meio da testa e n'uma 
Regiane Augusto de Mattos

das sobrancelhas, ainda boçal. Ao mesmo fugio a 4 dias, um mulato de altura ordinaria palido, sem barba, de nome Pedro, official de carapinteiro. ${ }^{4}$

A D. Maria Joaquina Pinheiro do Amaral fugio a 5 do Corrente março um escravo de nome Francisco, de nação Mina, com risco em ambas as faces, de edade de 19 a 20 annos, bem preto, alto, sem barba, com uma cicatriz no beiço de cima, da parte esquerda, que vai até o nariz, olhos pequenos, direito de corpo: é pedreiro e levou uma grande trou-

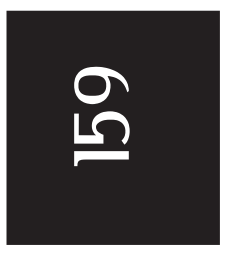
xa de roupa sua. Quem o prender entregará n'esta cidade a Francisco de Assis Pinheiro e Prado, de quem receberá as alviçaras. $^{5}$

As fontes documentais analisadas apresentam dados mais detalhados a respeito dos grupos étnicos dos africanos. Procuram mostrar uma preocupação em distinguir os africanos, identificando de forma mais minuciosa as diferentes "nações africanas", destacando os respectivos sinais físicos. Dessa maneira, a identificação étnica aparece como elemento primordial no conjunto das informações sobre determinado cativo.

Assim como os anúncios de escravos fugidos, os que oferecem cativos à venda também possuem uma forte tendência à distinção entre os africanos, bem como à identificação dos seus diversos grupos étnicos.

$\mathrm{Na}$ Rua Direita n.2 ha para vender uma negrinha nova, nação Benguella, meia ladina, sabendo já o serviço da casa por d'entro, e sem defeito nem-um. Quem quizer comprar queira aparecer na mesma casa, e tractar com o Sr. d'ella. ${ }^{6}$

Algumas informações pareciam necessárias para se oferecer um escravo, encontrando-as na maior parte dos anúncios. Diziam respeito às aptidões para determinado tipo de trabalho: se a principal função era de lavadeira, quitandeira, sapateiro ou 
A África no Brasil: grupos étnicos e organização social em São Paulo...

cozinheira; a algum defeito ou problema de saúde, à idade e origem. Ressaltamos que os grupos étnicos eram dados recorrentes, tendo em vista a freqüência com que aparecem no conjunto das fontes documentais.

Quem quizer comprar uma escrava de nação mossambique, de boa estatura e de idade 13 para 14 annos, sem molestia, senão algum, e com boas [...]ções, e sem vicio algum, (e já remedeia para cozinhar, lavar roupa, e vender quitanda); quem intentar na dicta compra procure falar com o dono que mora em o Pateo de S. Francisco em uma caza de n.12. ${ }^{7}$

Neste caso, se somarmos as três áreas do continente africano que abasteciam o tráfico de escravos para a América, isto é, Centro-Oeste, Ocidental e Oriental, encontramos referência aos grupos de origem em 82,48\% dos escravos fugidos e à venda. Enquanto que as designações genéricas como "da Costa", "gentio da Guiné", "de nação" (agrupado no termo África), aparecem em $17,52 \%$ dos escravos anunciados.

Observamos que os próprios senhores donos de escravos mostravam-se preocupados em identificar e distinguir a população africana. Um aspecto relevante para explicar essa distinção é a forte idéia que se vinculava na época a respeito do africano. Vemos na historiografia sobre a escravidão que, segundo o pensamento na época, o escravo nascido no âmbito da sociedade local era considerado facilmente dominado. Já o africano era visto como mais rebelde, um elemento perigoso ao resto da população, necessitando ser vigiado a maior parte do tempo. Inclusive a distinção entre as diversas "nações" passava por esse âmbito da periculosidade africana. Tratava-se da propriedade e procedência dos cativos, bem como das suas características específicas, que poderiam fazer parte da estratégia de dominação, utilizada como forma de controle da escravaria.

Anos 90, Porto Alegre, v. 12, n. 21/22, p.151-172, jan./dez. 2005 
Regiane Augusto de Mattos

Tabela 3 - Origem dos escravos africanos fugidos e à venda

\begin{tabular}{lrr}
\hline Área da África & Total & \multicolumn{1}{c}{$\%$} \\
\hline Centro-Oeste1 & 85 & 48,03 \\
Oriental $^{2}$ & 52 & 29,37 \\
África $^{3}$ & 22 & 12,42 \\
Ocidental $^{4}$ & 9 & 5,08 \\
da Costa & 6 & 3,40 \\
Guiné & 3 & 1,70 \\
Total & 177 & 100,00 \\
\hline
\end{tabular}

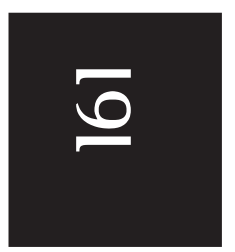

Fonte: AESP, O Farol Paulistano, 1828-1831, 03.03.004, 03.03.005 (microfilme); $A$ Phenix, 03.04.027 (microfilme).

${ }^{1}$ Essa expressão abrange os grupos cabinda, benguela, congo, rebolo, angola, munjolo, cassange, cabundá, moxicongo.

${ }^{2}$ Essa expressão abrange os grupos moçambique e quilimane.

${ }^{3}$ Essa expressão abrange o termo "de nação".

${ }^{4}$ Essa expressão abrange os grupos mina e nagoa.

Obs.: há um registro de "nação nambana” não classificado.

Também o discernimento das características dos grupos étnicos de africanos, pelos proprietários de escravos, poderia ser ocasionado por um interesse comercial. Seria necessário, no momento da compra, avaliar os aspectos físicos, como idade e condições de saúde, bem como ter a noção de qual o melhor grupo étnico para exercer uma determinada atividade, de acordo com a que já praticava na sua terra de origem. Saber o que estariam comprando e utilizando como mão-de-obra era uma preocupação recorrente.

Por outro lado, a preservação desse conhecimento também revela - e neste caso podemos incluir todas as camadas da sociedade -, um exercício de identificação acarretado pela convivência e pelo contato cotidiano com os diversos grupos étnicos de escravos e libertos oriundos do continente africano e que passaram a viver na cidade de São Paulo. Acredito que todos esses fatores 
A África no Brasil: grupos étnicos e organização social em São Paulo...

contribuem para explicar a prática da identificação étnica dos africanos.

\section{Batuques, capoeiras, irmandades: identidade étnica e formas de organização social}

Este artigo tem também por objetivo perceber como a identificação a determinados grupos étnicos direcionou formas de organização como a associação em irmandades religiosas, ajuntamentos em batuques, capoeira.

As irmandades negras são, muitas vezes, consideradas uma forma de conversão de africanos à doutrina e aos rituais católicos. No entanto, percebemos a possibilidade de esses africanos manifestarem suas tradições e visões de mundo. A festa da padroeira era um importante momento para a reunião entre negros escravos e libertos, africanos e nascidos na sociedade local. Nessas celebrações eles podiam ter um contato maior com seus irmãos de cor e de condição social, relembrando aspectos de sua própria cultura e assim promover a sua preservação.

Havia, no dia da festa da padroeira, uma mistura entre sagrado e profano. Escravos e libertos reuniam-se na Igreja para celebrar missas com sermão e procissão. Mas a festa não acabava aí, estendia-se pelas ruas do Largo do Rosário onde africanos desfilavam ao som de música de batuques. ${ }^{8}$ Assim como a festa da padroeira, a eleição e a coroação do Rei e da Rainha representavam um momento muito importante e de grande destaque para a Irmandade, bem como, para os indivíduos que ocupavam esses cargos. ${ }^{9}$

Por meio da leitura atenta do Compromisso verificamos, apenas quanto à ocupação desses cargos, a distinção de um determinado grupo étnico. $\mathrm{O}$ capítulo 22 destinava-se à regulamentação da eleição de um Rei e uma Rainha da Irmandade de N. Sra. do Rosário, especificando que esses membros deveriam ser do grupo

Anos 90, Porto Alegre, v. 12, n. 21/22, p.151-172, jan./dez. 2005 
angola. ${ }^{10}$ Nesse caso, observamos também a distinção entre os diferentes grupos étnicos, realizada por escravos e libertos dentro das irmandades. O papel de destaque fornecido à "nação angola", condicionando-a como elemento obrigatório à candidatura aos cargos de Rei e de Rainha da Irmandade, revela a existência da relação entre identidade étnica e organização social.

Os africanos de diferentes regiões que desembarcaram no Novo Mundo promoveram uma auto-identificação a grupos étnicos, reorganizando-se por meio destes e construindo, dessa ma-

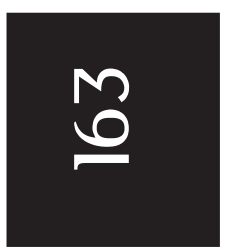
neira, uma identidade étnica. Portanto, identidade étnica é um conceito baseado na incorporação dos próprios africanos aos grupos étnicos definidos no momento da diáspora. Essa identidade étnica levava em conta afinidades e características que os africanos consideravam em comum, como a língua, a cultura, a ascendência que, muitas vezes, não imaginavam existir quando estavam no continente africano (Barth, 1997).

Dessa maneira, podemos entender a eleição de africanos do grupo angola para ocupar o principal cargo dessa associação religiosa. Talvez essa associação religiosa fosse organizada e administrada por esse grupo, por se encontrarem em maior número como irmãos ou componentes da Mesa de direção. De qualquer forma, havia uma notável preocupação dos próprios membros negros da Irmandade em distinguir os grupos de africanos e, a partir daí, se organizarem etnicamente.

No entanto, é preciso chamar a atenção para o fato de que não havia em nenhum capítulo do Compromisso a proibição à entrada ou à candidatura aos demais cargos da Mesa de africanos pertencentes a outros grupos étnicos. A eleição de destaque de um grupo étnico poderia funcionar como uma forma de acender rivalidades, dificultando alianças entre os africanos. Acredito que essa estratégia nem sempre funcionou. A permissão da entrada de qualquer grupo étnico na irmandade revela certa aproximação entre os diversos grupos, empregada até mesmo como uma estratégia 
A África no Brasil: grupos étnicos e organização social em São Paulo...

de sobrevivência. Quanto maior o número de pessoas conhecidas e de companheiros de condição, maior a rede de apoio e de solidariedade presentes nos momentos difíceis. Os negros elegeram no Novo Mundo os seus "parentes de nação", uma espécie de grande família simbólica, já que a de origem havia sido desmantelada ainda no continente africano. Esses "parentes de nação", muitas vezes, eram de grupos étnicos distintos.

No âmbito da cidade o escravo possuía uma maior mobilidade, podendo se deslocar no espaço das ruas, pontes, chafarizes com certa liberdade, tendo em vista o seu trabalho como vendedores ambulantes, quitandeiras e no serviço doméstico. Nos dias de folga, geralmente aos domingos e dias santos, escravos e libertos também se encontravam nas ruas e praças, ocasionando um contato entre africanos de diversas origens e outras camadas da população. Essa possibilidade de deslocamento pela cidade permitia uma interação mais intensa com momentos para a socialização, resultando numa mistura de costumes e manifestações culturais e religiosas.

Vemos, por meio dos Ofícios destinados ao Presidente da Província de São Paulo e outras autoridades locais, a descrição de ajuntamentos de negros, escravos e libertos. É o caso de um ofício do dia 12 de maio de 1829, escrito pelo Sr. Antonio Joaquim de S. Paio Santos ao Brigadeiro Francisco de Lima e Silva, Comandante de Armas da Província, requerendo que se faça uma patrulha aos domingos e dias santos no distrito de Santa Efigênia. Relata que há, sobretudo na ponte de Lorena, nesse distrito, "ajuntamentos" de escravos, que realizam danças e jogos, causando algumas desordens na região. ${ }^{11}$

Relatos recorrentes trazem informações sobre a prática de batuques por escravos e libertos. Segundo Mary Karasch (2001, p.330), o batuque é originário de uma dança chamada batuco, realizada na região de Angola pelos povos de Ambriz e Congo e também pelos povos de língua bunda, em torno de Luanda.

Anos 90, Porto Alegre, v. 12, n. 21/22, p.151-172, jan./dez. 2005 
Temos um registro de um casal e suas três filhas que foram obrigados a assinar um "termo de bem viver" por encontrarem em sua casa, na Freguesia do Ó, escravos praticando danças, batuques e jogos.

Relação das pessoas que assignarão termo de bem viver no Juizo de Paz da Freguesia de N. Senhora do Ó: Joze Luiz Alvarez Valensa, Ignacia Alvarez de Sequeira Mar. d'esta e suas tres filhas de nomes Francisca, Anna e Maria. Assignarão termo de bem viver por se portarem, com escandal-o da povoação ademettindo em sua casa batuques, jogos, escravos, originando-se por conseguinte duvidas, com acomminação de mez e meio de Cadêa, e multa na [...] das posturas da Camara a 3 de setembro de 1834. Freguesia d'Ó 6 de setembro de 1834. Joaquim Rodriguez Gulart. Juiz de Paz. ${ }^{12}$

Outra prática, muito comum entre escravos e libertos, era a capoeira. Vemos que essa manifestação era muito recorrente e empregada não apenas por escravos e libertos, mas também entre pessoas livres. Conhecida como um jogo de escravos, a capoeira tomava grande parte das discussões na Câmara Municipal, com o objetivo de estabelecer a sua proibição.

O ofício abaixo, da Câmara Municipal de São Paulo ao Presidente da Província, nos fornece uma idéia da preocupação em coibir esse "jogo de escravos":

Em resposta ao Officio de V. Exa. do 1o. mez findo comunicando haver o Exmo. Conselho do Governo resolvido recomendar a esta Camara Municipal providenciasse por meio de postura adaptadas a cohibir o jogo de escravos vulgarmente chamado Capoeira; a mesma participa a V. Exa. Que este objeto já se acha providenciado pelo artigo 18 das Posturas em vigor, sendo por tanto desnecessario em novo artigo. Deos Guarde a V. Exa. Páco da Camara em S. Paulo 17 novembro de 1832. Illmo e Examo Snr Presidente da Província. ${ }^{13}$ 
A África no Brasil: grupos étnicos e organização social em São Paulo...

A origem da capoeira é um pouco incerta. Muitos afirmam que consistia numa prática dos escravos que tinha por objetivo proteger as mercadorias que carregavam em cestas conhecidas como capoeiras. Era muito praticada nas cidades, sobretudo por negros de ganho, que circulavam vendendo alimentos nas ruas, mais tarde se consagrando uma dança, uma espécie de brincadeira feita por escravos e libertos, africanos ou não, nas horas vagas (Karasch, 2001, p.331).

A respeito da africanidade da capoeira, Carlos Eugênio Líbano Soares (2004, p.143), ao estudar a capoeira escrava no Rio de Janeiro, entre 1808 e 1850, aponta para a existência de danças marciais no Caribe com origem em tradições do Congo, como a lagya, na Martinica e o mani ou bombosa, em Cuba. Ademais, utilizando-se de um artigo do pesquisador norte-americano John Thornton (apud Soares, 2004, p.143), sobre tradições dos antigos povos de Angola, Soares relata a presença de uma "dança de guerra" entre os povos do Reino do Congo, considerando-a como ponto de partida para o descobrimento de raízes africanas na capoeira.

No entanto, não era apenas na socialização nas ruas, becos e pontes que esses negros eram controlados. Até mesmo nas instituições religiosas católicas como as irmandades, as práticas ditas de "origem africana" eram proibidas. A festa da padroeira também era vigiada pelas autoridades locais. Ficavam terminantemente proibidos batuques, danças e cantorias que extrapolassem as procissões nas ruas da cidade. Vejamos o Ofício dirigido ao Governador de Armas da Província de São Paulo, solicitando a autorização de patrulhas durante a festa de N. Sra. do Rosário.

Agora, por parte do Rey de eleição para a festividade de N. Senhora do Rozario dos homens pretos desta cidade, se me reprezentou requerimento pelo qual obtive licença do Illmo. Exmo. Senhor Prezidente, para com os das Naçoens Africanas, fazer a Funções da Festividade da dita 
Senhora, cuja Licença foi concedida com prohibições, porem, de danças e ajuntamentos pelas ruas; sendo o dito Exmo. Senhor, servido incumbir-se das medidas necessarias a leva da manutenção do socego publico, como tudo tem, V. Excia prezente na copia incluza, e como pelas forças da Justiça não me he possivel vigiar sobre tal negocio, devo recorrer á Força Armada, pela qual he facil acautellar a contravenções do respeitavel despacho do Exmo. Snr. Prezidente, por isso depreco a V. Excia. para que se digne ordenar que as Patrulhas que ouverem de sahir pela cidade nas tardes desta Festa, saião logo de manhã, ordenando-se as ditas patrulhas, extorvem as taes danças, toques de tambores de que vizão os taes africanos, e ajuntamentos perturbadores. D. El guarde a V. Excia S. Paulo 25 dezembro de 1829.

Illmo. Exmo. Snr. Governador de Armas desta Província. (grifos meus). ${ }^{14}$

Vemos, nesse exemplo, a prática de danças, toques de tambores, ajuntamento de africanos que "perturbavam" o restante da população depois de realizada a festa da padroeira da Irmandade. As patrulhas eram solicitadas para conter tais "excessos" da festa religiosa e manter o "sossego público".

No entanto, um maior controle era destinado às práticas africanas relacionadas aos cultos mágico-religiosos. No capítulo 8 do Compromisso da Irmandade de N. Sra. do Rosário, fica determinada a expulsão do irmão que cometer qualquer tipo de feitiçaria ou fazer uso de ervas. "E tão bem terá cuidado saber se há algum Irmão ou Irmã que uze de ervas, ou feitiçarias, e havendo estes taes, serão logo expulsos da Irmandade sem remissão algua." ${ }^{15}$ Curandeiros e mães-de-santo eram personagens sempre perseguidos pela legislação e autoridades locais. Possuíam grande influência, pois tratava-se de líderes religiosos.

Constatamos, por meio dos registros religiosos, dos anúncios de escravos fugidos e à venda em jornais e da historiografia sobre o tráfico de escravos, que a maior parte de africanos vindos para a 
A África no Brasil: grupos étnicos e organização social em São Paulo...

região sudeste do Brasil e, especificamente, para São Paulo saíram da área Centro-Oeste da África, isto é, eram povos de origem bantu. Esse vocábulo abrange vários povos e culturas que ocupam mais de nove milhões de quilômetros quadrados da África e que se localizam entre a baía de Biafra, a oeste e Melinde, a leste, e se estende aos grupos étnicos africanos do centro, do sul e do leste do continente, que possuem características e modos de vida semelhantes, abarcando um conjunto de mais de 300 línguas com aspectos em comum, tal como a conjugação dos verbos. Entre eles estão os mbundu, que habitavam Angola, ao Norte do rio Cuanza, cuja língua é o kimbundu; os ovibundu ao sul desse rio, que falavam o umbundu, e os bakongos, localizados no Congo, em Cabinda e no norte de Angola e cuja língua é o kikongo (Lopes, 1988, p.86).

Pela tradição africana de origem bantu, além dos ancestrais, outros indivíduos da sociedade recebem um caráter de sacralidade por serem dotados de uma grande quantidade de energia vital, como o rei, os chefes, o pai, os ligados à religião e à magia.

Em obra de Craemer, Vansina e Fox (apud Slenes, 1999), analisando os movimentos religiosos da África Central, assinalase o "complexo cultural ventura-desventura" (fortune-misfortune), no qual o universo é composto por saúde, equilíbrio e harmonia. Tudo o que lhe é contrário, tal como a doença e o desequilíbrio, são acarretados pelos espíritos do mal, muitas vezes por meio da feitiçaria. Por exemplo,

[...] os bakongos esperam levar vidas saudáveis, prósperas e satisfeitas, ter sucesso em seus empreendimentos e ter famílias grandes. Qualquer coisa menos que isso é anormal, indicando a influência de alguma forma de kindoki. Kindoki, geralmente traduzido como "feitiçaria", vem da raiz loka (literalmente "ficar vermelho"), que significa "fazer feitiçaria, praticar magia negra, atacar, matar por meios mágicos"; ndoki, "feiticeiro". (Karasch, 2000, p.567). 
Esses grupos étnicos africanos, que eram conhecidos no Novo Mundo como simplesmente angola, congo, cabinda, benguela, ou seja, nomes de portos de embarque, mercados e reinos africanos, se reconheceram como tais, identificando afinidades como traços semelhantes da língua, da cultura e da cosmologia, como a importância ao culto dos ancestrais, da organização por meio das relações de parentesco e de etnia e que não imaginavam existir quando estavam no continente africano. Na cidade de São Paulo, esses grupos que hoje conhecemos como bantus, estabeleceram formas de socialização, promovendo manifestações culturais como o batuque, a capoeira e organizações religiosas como as irmandades negras, redefinindo espaços por meio da identidade étnica.

Africa in Brazil: etnhic groups and social organization in São Paulo on XIX ${ }^{\text {th }}$ Abstract. The purpose of this article is to present a profile of the ethnic groups of African people in the city of São Paulo in the first half of the 19th century, pointing out their forms of social organization, in particular their cultural and religious manifestations. It is intended to argue, based on the concept of the ethnic group supplied by the anthropologist Frederik Barth, the forms of attribution and identification of these groups by external agents as the Catholic Church and the proprietors of slaves. This concept also has as estimated the incorporation by the African people themselves who had identified with these ethnic groups, directing their forms of organization, after all, by the means of the association in religious brotherhoods, "audiences" in batuques, capoeiras and dances. The intention is to perceive as the incorporation of determined ethnic groups directed the organization forms, the manifestations of their traditions by the means of the cultural and religious aspects, the relation with different ethnic groups and with others social classes.

Keywords: African people. Ethnic groups. Forms of social organization. 
A África no Brasil: grupos étnicos e organização social em São Paulo...

\section{Notas}

${ }^{1}$ Em 1719, foram publicadas as Constituições Primeiras do Arcebispado da Babia, a primeira tentativa de regulamentação da doutrina da Igreja Católica na colônia. Eram as Constituiçoes que estabeleciam as diretrizes para os assentos de batismo, óbito e casamento. Com relação à identificação étnica dos escravos africanos, esse código não traz detalhamento algum ou condição específica. Apenas se refere à existência de cativos da Guiné, Angola e Costa da Mina. Cf. Constituições Primeiras do Arcebispado da Babia feitas e ordenadas pelo ilustríssimo, e reverendíssimo senhor D. Sebastião Monteiro da Vide 5o. arcebispo do dito Arcebispado, e do Conselho de sua Magestade: propostas e aceitas em o Sinodo Diocesano, que o dito senhor celebrou em 12 de junho do anno de 1707. 1a. edição Lisboa, 1719, e Coimbra, 1720. São Paulo: Typographia 2 de Dezembro de Antonio Louzada Antunes, 1853.

${ }^{2}$ Sobre as regiões no continente africano que abasteciam o tráfico de escravos ver Florentino (1995) e Karasch (2000).

${ }^{3}$ Arquivo do Estado de São Paulo (AESP), O Farol Paulistano, SP, 19 de junho de 1830, 03.03 .005 (microfilme).

${ }^{4}$ Idem, 5 de agosto de 1829, 03.03 .004 (microfilme).

${ }^{5}$ Idem, 15 de março de 1828, 03.03.004 (microfilme).

${ }^{6}$ Idem, 18 de outubro de 1828, 03.03.004 (microfilme).

${ }^{7}$ Idem, 2 de novembro de 1830, 03.03 .005 (microfilme).

8 "Por ocasião das solenidades que, antigamente, se efetuavam na igreja de Nossa Senhora do Rosário, em honra desta Santa, se realizavam também, em frente à mesma igreja, festejos populares, postando-se aí um numeroso bando de pretos africanos, que executavam, com capricho, a célebre música denominada Tambaque (espécie de Zé Pereira), cantando e dançando com as suas parceiras, que adornadas de rodilha de pano branco na cabeça, pulseira de prata, e de rosário de contas vermelhas e de ouro no pescoço, pegavam no vestido e faziam requebrados, sendo por isso vistoriados com uma salva de palmas pela numerosa assistência [...]" (Martins, 1912, v. II, p. 82).

9 “[...] e quando terminava a festa da Igreja, os mesmos africanos acompanhavam, tocando quantos instrumentos esquisitos haviam, e cantando, o Rei e a Rainha, com a sua corte, composta de grande número de titulares e damas, que se apresentavam muito bem vestidos. O Rei e a Rainha, logo que chegavam em casa, ofereciam aos mesmos titulares (títulos que então possuíam os antigos estadistas do tempo do Império) e às damas um opíparo jantar, durante o qual trocavam-se amistosos brindes entre os convivas, mandando as majestades distribuir bebidas aos tocadores de tambaque que ficavam na rua esperando a saída das mesmas

Anos 90, Porto Alegre, v. 12, n. 21/22, p.151-172, jan./dez. 2005 
Regiane Augusto de Mattos

personagens. Estas voltavam para a igreja a fim de tomarem parte na solene procissão de N. Sra. do Rosário.” (Martins, 1912, v. II, p.82-83).

${ }^{10}$ ACMSP, Compromisso da Irmandade de N.Sra. do Rosário. Livro 1-3-8, Capítulo 22, p.7.

${ }^{11}$ AESP. Ofícios Diversos da Capital. C00866, pasta 2, doc 80.

${ }^{12}$ AESP. Ofícios Diversos da Capital, C00870, pasta 2, doc 64.

${ }^{13}$ Idem, C00868, pasta 2, doc 58.

${ }^{14}$ AESP. Ofícios Diversos da Capital. C00866, pasta 3, doc. 85.

${ }^{15}$ ACMSP. Compromisso da Irmandade de N. Sra. do Rosário dos Homens Pretos. Livro 3-1-8, Capítulo 8, f. 4 verso.

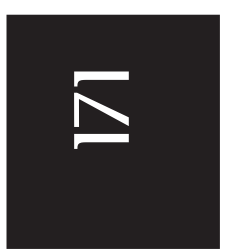

\section{Referências}

BARTH, Fredrik. Grupos étnicos e suas fronteiras. In: POUTIGNAT, Philippe; STREIFF-FENART, Jocelyne. Teorias da etnicidade. São Paulo: Editora Unesp, 1997.

FLORENTINO, Manolo Garcia. Em costas negras; uma história do tráfico atlântico de escravos entre a África e o Rio de Janeiro (século XVIII e XIX). Rio de Janeiro: Arquivo Nacional, 1995.

KARASCH, Mary. A vida dos escravos no Rio de Janeiro (1808-1850). São Paulo: Cia das Letras, 2000.

LOPES, Nei. Bantos, Malês e identidade negra. Rio de Janeiro: Forense Universitária, 1988.

MARTINS, Antonio Egidio. São Paulo Antigo. São Paulo: Tipografia do Diário Oficial, 1912. v. II.

RUSSEL-WOOD, A. J. R. Através de um prisma africano: uma nova abordagem ao estudo da diáspora africana no Brasil colonial. Tempo, n. 12, p.11-50, 2001.

SLENES, Robert. Na senzala uma flor; esperanças e recordações na formação da família escrava, Brasil, Sudeste, século XIX. Rio de Janeiro: Nova Fronteira, 1999.

SOARES, Carlos Eugênio Líbano. A capoeira escrava e outras tradições rebeldes no Rio de Janeiro (1808-1850). 2. ed. ver. e ampl. Campinas, SP: Editora da Unicamp, 2004. 
A África no Brasil: grupos étnicos e organização social em São Paulo...

SOARES, Mariza de Carvalho. Devotos da Cor. Identidade étnica, religiosidade e escravidão no Rio de Janeiro, século XVIII. Rio de Janeiro: Civilização Brasileira, 2000.

THORNTON, John K. The art of war in Angola, 1575-1680. Comparative study of Society and History, v.30, n.2, p.368-371, abr. 1988. 